\title{
Verification of Hazard Analysis and Critical Control Point in Hotels and Catering Units: Evaluation of the Cleaning and Disinfection Procedures and Microbiological Monitoring of Hot and Cold Meals
}

\author{
Constantina Nasopoulou ${ }^{1}$, Panagiotis Poulios ${ }^{1}$, Mania Magli ${ }^{1}$, Nikolaos Gdontelis ${ }^{2}$, \\ Constantinos Papanotas ${ }^{2}$, Ioannis Zabetakis ${ }^{1 *}$ \\ ${ }^{1}$ Laboratory of Food Chemistry, Department of Chemistry, National and Kapodistrian University of Athens, Athens, Greece; ${ }^{2}$ Appert \\ S.A., Athens, Greece. \\ Email: "izabet@chem.uoa.gr
}

Received December $8^{\text {th }}, 2011$; revised February $17^{\text {th }}, 2012$; accepted February $25^{\text {th }}, 2012$

\begin{abstract}
The aim of the present study is to assess the efficacy of the methods used in a HACCP system by measuring the Total Viable Count (TVC) and Coliforms, after cleaning and disinfecting the surfaces used and also by monitoring TVC and enterobacteriaceae of hot and cold meals. In order to evaluate the appropriateness of the surfaces used, samples were obtained from kitchens of 37 Greek hotels/resorts, all of which operated a documented HACCP safety management scheme, while the samples of hot and cold meals were selected from the menu of a catering unit and collected from the actual point of hot and cold dishes banquette at the start time (time 0 ) and after 4 hours. The developed colonies were counted. The results showed that only $13.5 \%$ of the hotels presented surfaces without any TVC or coliforms and $86.5 \%$ of the hotels had surfaces with TVC or coliforms or both above the limits. However, $75.8 \%$ of the total surfaces examined were acceptable for TVC and $81.9 \%$ of the surfaces examined were coliforms. Our microbiological monitoring of food showed that the TVC content of hot meal samples after 4 hours of display (above $60^{\circ} \mathrm{C}$ ) was not significantly different from the TVC content of the aforementioned samples at time 0 , while in cold meals TVC and enterobacteriaceae content had significantly risen after 4 hours of display (below $5^{\circ} \mathrm{C}$ ). Conclusively, insufficient application of disinfection and ineffective surface and equipment cleaning programs were found. Additionally, cold meals are more vulnerable than hot meals in developing TVC and enterobacteriaceae.
\end{abstract}

Keywords: HACCP; Food Safety; TVC; Coliforms; Enterobacteriaceae; GHP; Cutting Surfaces; Hot Meals; Cold Meals

\section{Introduction}

The Greek law 487 [1] that came into force in 2000 and the European law 852/2004 (EC Regulation 852/2004) [2] require that all food business, except those involved in primary production, implement Good Hygienic Practice (GHP) in combination with Hazard Analysis and Critical Control Point (HACCP) system. Implementation of HA$\mathrm{CCP}$, includes the implementation of the Pre-requisite Programs (PRPs) [3,4]. According to ISO22000:2005 [4], PRPs are the basic conditions and activities which are essential for the maintenance of a suitable and healthy environment in the various stages of foods production and for the handling and supplying of safe products and foods which are intended for human consumption. Some of the PRPs needed for the implementation of HACCP

\footnotetext{
"Corresponding author.
}

are the infrastructure, the training of the personnel, Good Hygienic Practice (GHP) and Good Manufacture Practice (GMP) $[2,5,6]$.

The aim of this study was to determine whether GHP and GMP were being applied adequately by measuring the TVC and Coliform content of surfaces used in kitchens of 37 Greek hotels/resorts and also by measuring the TVC and Enterobacteriaceae content of hot and cold meals of a catering unit which served 300 meals per day $[7,8]$. Parameters such as, the accurate implementation of the cleaning programs, the disinfection of the kitchens, personal hygiene, proper handling of food ingredients and the correct implementation of heating processes as well, are the essential prerequisites for satisfactory implementation of HACCP that ensures the safety of produced food [3]. 
In our study, hot meals stand for the foodstuffs that have been under thermal processing and are preserved above $60^{\circ} \mathrm{C}$, while cold meals describes foodstuffs in refrigerated displays below $5^{\circ} \mathrm{C}$. The presence of Coliforms and Enterobacteriaceae are factors of food quality and signs of unhygienic conditions or insufficient implementation of GHP during or after food production. Also, the detection of Coliforms and Enterobacteriaceae make possible the presence of pathogenic bacteria. By counting Coliforms and Enterobacteriaceae, the quality of food and quality of used practices may also be evaluated $[9,10]$. The efficacy of the applied GHP and GMP was assessed by measuring the Total Viable Count (TVC) and Coliforms after the cleaning and disinfection of the surfaces and by measuring the TVC and Enterobacteriaceae content in both hot and cold meals after 4 hours of display.

\section{Materials and Methods}

\subsection{Materials}

In the present study, ready sterilized contact plates, "Envirocheck Contact C, 1.02136.0001" (Merck, Germany) were used, for surfaces analysis [11]. The exceptional feature of these particular contact plates, is its double surface, as each surface has a different constitution of substrate. One side (Side 1), contains the "Plate Count Agar", which is a substrate suitable for the isolation and measurement of TVC [12] while the other side (Side 2) contains the "Chromocult-Coliform Agar", which is suitable for the isolation and measurement of Coliforms [11]. For sampling of cold and hot meals, the temperatures of the samples during the display were recorded with a digital thermometer (Ebro Electronics $\mathrm{GmbH} \&$ Co., Kologne, Germany). A portable refrigerator was used for the transportation of the samples to the laboratory, whilst utilizing a digital thermometer (Ebro Electronics $\mathrm{GmbH} \&$ Co., Kologne, Germany), to maintain temperature at $2^{\circ} \mathrm{C}-4^{\circ} \mathrm{C}$ [11]. The samples were incubated in a furnace, operating at $37^{\circ} \mathrm{C} \pm 1{ }^{\circ} \mathrm{C}$ [12]. Also, in order to count the colonies developed on the sterilized contact plates, a meter of colonies (Bibby Sterilin Ltd., UK), was used. For the analysis of Enterobacteriaceae, contact plates with Violet Red Bile Glucose Agar (Bibby Sterilin Ltd., UK) were used.

\subsection{Samples Collection and Preparation}

All experimental work was carried out in Laboratories of food and drinks, Analysis and Testings, "APPERT", including the collection, treatment, registration and analysis of all samples. The first step was the collection of samples from various surfaces, of the kitchens of the hotels/resorts and their transfer in portable refrigerators, to the laboratories, for analysis. Ready sterilized contact plates of Merck "Envirocheck Contact C, 1.02136.0001" were used [11]. All samples were taken aseptically from the kitchen's surface. With great caution, the protective cover was opened and the contact plate was carefully removed and placed on the surface sample and the edges of the contact plate were gently pressed with two fingers, so that it applied well to the examination surface [11]. For food sampling, at the start and at the end of the 4 hours long display period, food samples were taken from the display areas using aseptic tools and stored in sterile food containers.

At each sampling of either surfaces or food, three replicate samples were obtained and all results are given as mean values \pm standard deviation $(95 \%$ confidence levels). At the end of all sample collections, samples were placed into a portable refrigerator, containing ice chests and transported to the laboratory for analysis. The temperature was maintained at $2^{\circ} \mathrm{C}-4^{\circ} \mathrm{C}$ [11]. At the laboratory, the samples were registered, coded and incubated at $37^{\circ} \mathrm{C}$ for either 24 or 48 hours.

\subsection{Methods}

TVC analysis: following the 48 hour incubation, the colonies that had developed, were counted on each side of the contact plate, separately, using a meter of colonies (Bibby Sterilin Ltd. UK). Consequently, all the white colonies on the one side (Side 1) and all the red colonies on the other side (Side 2) were counted, with the help and comparison of Merck protocol $[10,11]$. The method used for the detection and numeration of TVC was semiquantitative.

Coliforms' analysis: the method used was based on the detection of the enzyme $\beta$-galactosidase which is characteristic for this group, with the help of chromogen substrate 6-chloro-3-indoxyl-3 $\beta$-D-galactopyranoside (SALMON-GAL). The hydrolysis of this substrate, by $\beta$-galactosidase, produces chromogen complex which shapes the characteristic red colonies [11].

Enterobacteriaceae's analysis: contact plates with Violet Red Bile Glucose Agar were incubated at $37^{\circ} \mathrm{C} \pm 1{ }^{\circ} \mathrm{C}$ for 24 hours. Pink to red or purple colonies, with or without precipitation zones, were confirmed as Enterobacteriaceae, after subculturing selected colonies onto Nutrient agar plates, with oxidase test (negative result) and fermentation of glucose (positive result). The analytical method was according to ISO 21528-2:2004 [12] and ISO 18593:2004 [13].

\section{Results and Discussion}

All the hotels checked in this study were implementing 
HACCP and sampling took place only when all the procedures of cleaning and disinfection had been completed. Working surfaces and cutting boards, were checked. The results are given as: the number of total surfaces that have been checked in each hotel, how many of the total surfaces were found to be completely clean, the number of surfaces with TVC and coliforms above the limits and finally the number of surfaces with only coliforms above the limits (Figure 1).

The limit for TVC-coliforms was $12 \mathrm{cfu} \cdot \mathrm{cm}^{-2}$ and for coliforms was $1 \mathrm{cfu} \cdot \mathrm{cm}^{-2}[14,15]$. As shown in Figure 1, hotels may be separated in two categories. Those which had all clean surfaces and presented acceptable results and those which had some surfaces out of limits. Five of the hotels belong to first category and the rest to the second one. This fact means that only $13.5 \%$ of the hotels presented surfaces without any TVC or coliforms and $86.5 \%$ of the hotels had surfaces with either TVC or coliforms or both above the limits. The second part of this study was to separate and check the surfaces depending on the kind of the food, which it came into contact with. Three kinds of foods were used: the readyto-eat, the non-ready-to-eat and general foods. The first category includes foods which do not need any kind of thermal treatment such as fruits, vegetables, salads, cheeses, deserts and foods that have already been cooked [16]. The second category [16] includes raw foods which need treatment, such as cooking, and includes mostly meats. The third category is used for the surfaces that we did not know exactly the kind of food that they came into contact with or which were used for foods from both of the categories, mentioned above.

Regarding the results of Table 1, overall $75.8 \%$ of the total surfaces examined were acceptable for TVC and $81.9 \%$ of the surfaces examined were coliforms. $72.5 \%$ of the surfaces which came into contact with ready-to-eat foods and $77.8 \%$ of those which came into contact with non-ready-to-eat foods were found acceptable for TVC.

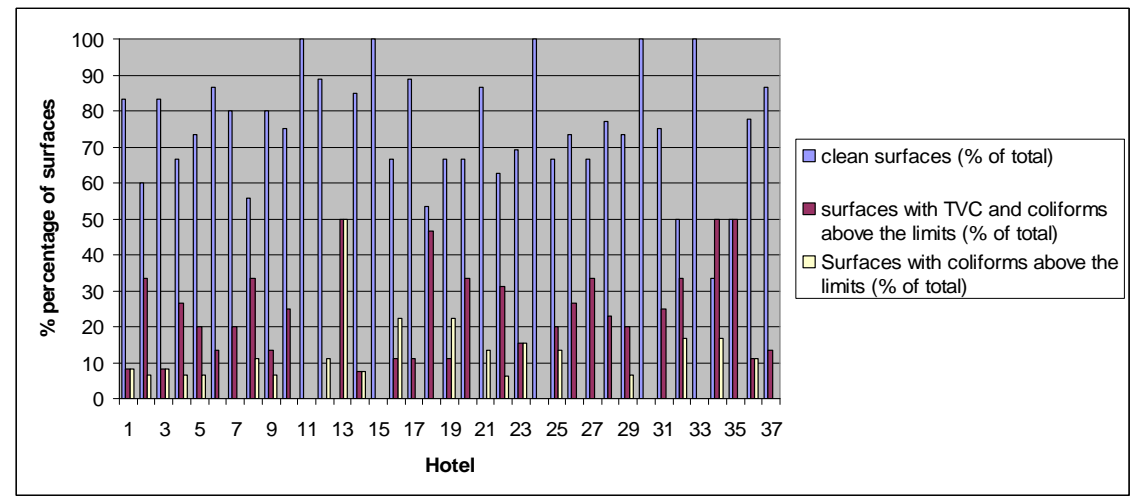

Figure 1. The percentage of the total surfaces found clean, with TVC and coliforms above the limits and with coliforms above the limits.

Table 1. Measurements of TVC and coliforms on three categories of surfaces.

\begin{tabular}{|c|c|c|c|c|c|}
\hline \multirow{2}{*}{\multicolumn{2}{|c|}{ Measurements of TVC \& Coliforms }} & \multicolumn{4}{|c|}{ Type of food in contact with surfaces } \\
\hline & & $\begin{array}{c}\text { Ready-to-eat } \\
(\mathrm{n}=211)\end{array}$ & $\begin{array}{l}\text { Non-ready-to-eat } \\
\quad(\mathrm{n}=126)\end{array}$ & $\begin{array}{l}\text { General foods } \\
\quad(\mathrm{n}=105)\end{array}$ & $\begin{array}{l}\text { Total surfaces } \\
\quad(\mathrm{n}=442)\end{array}$ \\
\hline \multirow{5}{*}{$\operatorname{TVC}\left(37^{\circ}\right)$} & $\begin{array}{c}\text { Acceptable } \\
<\mathbf{1 2} \mathrm{cfu} \cdot \mathrm{cm}^{-2}(\%)\end{array}$ & $\begin{array}{c}72.5 \\
(n=153)\end{array}$ & $\begin{array}{c}77.8 \\
(\mathrm{n}=98)\end{array}$ & $\begin{array}{c}\mathbf{8 0 . 0} \\
(\mathrm{n}=84)\end{array}$ & $\begin{array}{c}75.8 \\
(n=335)\end{array}$ \\
\hline & $\begin{array}{l}\text { Not acceptable } \\
17 \mathrm{cfu} \cdot \mathrm{cm}^{-2}(\%)\end{array}$ & $\begin{array}{c}16.6 \\
(\mathrm{n}=35)\end{array}$ & $\begin{array}{c}12.7 \\
(\mathrm{n}=16)\end{array}$ & $\begin{array}{c}14.3 \\
(n=15)\end{array}$ & $\begin{array}{c}14.9 \\
(n=66)\end{array}$ \\
\hline & $\begin{array}{l}\text { Not acceptable } \\
58 \mathrm{cfu} \cdot \mathrm{cm}^{-2}(\%)\end{array}$ & $\begin{array}{c}\mathbf{9 . 9} \\
(n=21)\end{array}$ & $\begin{array}{c}9.5 \\
(\mathrm{n}=12)\end{array}$ & $\begin{array}{c}4.8 \\
(n=5)\end{array}$ & $\begin{array}{c}8.6 \\
(n=38)\end{array}$ \\
\hline & $\begin{array}{l}\text { Not acceptable } \\
140 \mathrm{cfu} \cdot \mathrm{cm}^{-2}(\%)\end{array}$ & $\begin{array}{c}\mathbf{0 . 9 4} \\
(\mathrm{n}=2)\end{array}$ & - & $\begin{array}{c}\mathbf{0 . 9} \\
(\mathrm{n}=1)\end{array}$ & $\begin{array}{c}0.68 \\
(n=3)\end{array}$ \\
\hline & $\begin{array}{l}\text { Not acceptable } \\
350 \mathrm{cfu} \cdot \mathrm{cm}^{-2}(\%)\end{array}$ & - & - & - & - \\
\hline \multirow{2}{*}{ Total Coliforms } & $\begin{array}{c}\text { Acceptable } \\
<\mathbf{1} \mathrm{cfu} \cdot \mathrm{cm}^{-2}(\%)\end{array}$ & $\begin{array}{c}\mathbf{7 8 . 2} \\
(\mathrm{n}=165)\end{array}$ & $\begin{array}{c}\mathbf{8 4 . 9} \\
(\mathrm{n}=107)\end{array}$ & $\begin{array}{c}\mathbf{8 5 . 7} \\
(\mathrm{n}=90)\end{array}$ & $\begin{array}{c}81.9 \\
(n=362)\end{array}$ \\
\hline & $\begin{array}{l}\text { Not acceptable } \\
>1 \mathrm{cfu} \cdot \mathrm{cm}^{-2}(\%)\end{array}$ & $\begin{array}{c}21.8 \\
(n=46)\end{array}$ & $\begin{array}{c}15.1 \\
(n=19)\end{array}$ & $\begin{array}{c}14.3 \\
(n=15)\end{array}$ & $\begin{array}{c}18.1 \\
(n=80)\end{array}$ \\
\hline
\end{tabular}


Additionally, $80 \%$ of the surfaces used for general foods were also acceptable for TVC. The percentage of acceptable surfaces for coliforms was found to be higher for all three categories of foods than the corresponding percentage for TVC. Specifically, $78.2 \%$ of the surfaces which came into contact with ready-to-eat foods, $84.9 \%$ of those which came in contact with non-ready-to-eat foods and $85.7 \%$ of the surfaces used for general foods, were acceptable for coliforms.

According to the results, it was observed that there were more surfaces which came into contact with readyto-eat foods which were above the limits, both for TVC and coliforms, than for the surfaces which came into contact with non-ready-to-eat foods. A great deal of attention should be paid to this fact, because the ready-toeat foods will not undergo any thermal treatment, so the microorganisms will remain on the food and could potentially cause problems to the consumers. A possible explanation for these results is that the handlers of these types of food, such as fruits and vegetables, may consider themselves as harmless and they neglect to wash the surfaces that they came into contact with, according to GHP. So, some food cross-contamination is possible while food is being handled on these surfaces. The high percentage of the not acceptable surfaces for the non-readyto-eat foods, suggests that in one or more stages of the production or the preparation of these foods, the disinfection and hygiene programs were insufficient.

The presence of TVC or coliforms is the result of the insufficient implementation of GHP and HACCP [17]. However, the quality of foods is dependant upon the sufficient implementation of HACCP and also GHP [18] in both the preparation and processing procedures. The insufficient application of these programs reduces the quality and the safety of the food [19] and increases the possibility of food-borne outbreaks [20].

The hotels, in which a high number of not acceptable surfaces were found, were recommended to improve the effectiveness of cleaning and disinfection programs of surfaces and equipment, which already existed by following exactly the instructions given by the adviser who initially implemented HACCP system, in their business. Given that the training and the education of the personnel and also the application of HACCP, constitute a legal requirement of Greek legislation [1], the results of our study, showed the insufficient and wrong application of disinfection and cleaning programs of surfaces and equipment during the food treatment. Also, they confirm the needs for immediate training and education of personnel in GHP, which lead to the correct implementation of HACCP and also for the evaluation of the efficacy of these training programs.

The third part of our study focused on the microbi- ological monitoring of cold and hot meals. As a hot meal, cooked burgers were chosen and the levels of TVC were screened in 12 samplings at times $0 \mathrm{~h}$ (start of serving) and $4 \mathrm{~h}$ (end of serving) (Table 2).

TVC data were in the range of 1.00 to $1.48\left(\log _{10} \mathrm{cfu} / \mathrm{g}\right)$ at time $0 \mathrm{~h}$ whereas after 4 hours of display, values of TVC were found in the range of 1.00 to $1.70\left(\log _{10} \mathrm{cfu} / \mathrm{g}\right)$. For all measurements, the increase in TVC was lower than $0.2 \log _{10} \mathrm{cfu} / \mathrm{g}$. Only one quarter of the readings showed an (non statistically significant) increase in

Table 2. Measurements ${ }^{\mathrm{a}}$ of TVC in 12 samplings of baked burger at times $0 \mathrm{~h}$ (start of serving) and $4 \mathrm{~h}$ (end of serving).

\begin{tabular}{|c|c|c|c|}
\hline \multirow{3}{*}{ Sampling } & \multirow{3}{*}{ Time } & \multirow{2}{*}{\multicolumn{2}{|c|}{$\begin{array}{c}\text { Burger (baked) } \\
\text { TVC (log10 CFU/g) }\end{array}$}} \\
\hline & & & \\
\hline & & Range & Mean value \pm S.D. \\
\hline \multirow{2}{*}{$1^{\text {st }}$ sampling } & $0 \mathrm{~h}$ & $1-1.48$ & $1.26 \pm 0.24$ \\
\hline & $4 \mathrm{~h}$ & $1.30-1.48$ & $1.36 \pm 0.10$ \\
\hline \multirow{2}{*}{$2^{\text {nd }}$ sampling } & $0 \mathrm{~h}$ & $1-1.48$ & $1.16 \pm 0.28$ \\
\hline & $4 \mathrm{~h}$ & $1.30-1.48$ & $1.36 \pm 0.10$ \\
\hline \multirow{2}{*}{$3^{\text {rd }}$ sampling } & $0 \mathrm{~h}$ & $1-1.3$ & $1.2 \pm 0.17$ \\
\hline & $4 \mathrm{~h}$ & $1-1.7$ & $1.23 \pm 0.40$ \\
\hline \multirow{2}{*}{$4^{\text {th }}$ sampling } & $0 \mathrm{~h}$ & $<1$ & $1 \pm 0.00$ \\
\hline & $4 \mathrm{~h}$ & $<1$ & $1 \pm 0.00$ \\
\hline \multirow{2}{*}{$5^{\text {th }}$ sampling } & $0 \mathrm{~h}$ & $<1$ & $1 \pm 0.00$ \\
\hline & $4 \mathrm{~h}$ & $<1$ & $1 \pm 0.00$ \\
\hline \multirow{2}{*}{$6^{\text {th }}$ sampling } & $0 \mathrm{~h}$ & $<1$ & $1 \pm 0.00$ \\
\hline & $4 \mathrm{~h}$ & $<1$ & $1 \pm 0.00$ \\
\hline \multirow{2}{*}{$7^{\text {th }}$ sampling } & $0 \mathrm{~h}$ & $<1$ & $1 \pm 0.00$ \\
\hline & $4 \mathrm{~h}$ & $<1$ & $1 \pm 0.00$ \\
\hline \multirow{2}{*}{$8^{\text {th }}$ sampling } & $0 \mathrm{~h}$ & $<1$ & $1 \pm 0.00$ \\
\hline & $4 \mathrm{~h}$ & $<1$ & $1 \pm 0.00$ \\
\hline \multirow{2}{*}{$9^{\text {th }}$ sampling } & $0 \mathrm{~h}$ & $<1$ & $1 \pm 0.00$ \\
\hline & $4 \mathrm{~h}$ & $<1$ & $1 \pm 0.00$ \\
\hline \multirow{2}{*}{$10^{\text {th }}$ sampling } & $0 \mathrm{~h}$ & $<1$ & $1 \pm 0.00$ \\
\hline & $4 \mathrm{~h}$ & $<1$ & $1 \pm 0.00$ \\
\hline \multirow{2}{*}{$11^{\text {th }}$ sampling } & $0 \mathrm{~h}$ & $<1$ & $1 \pm 0.00$ \\
\hline & $4 \mathrm{~h}$ & $<1$ & $1 \pm 0.00$ \\
\hline \multirow{2}{*}{$12^{\text {th }}$ sampling } & $0 \mathrm{~h}$ & $<1$ & $1 \pm 0.00$ \\
\hline & $4 \mathrm{~h}$ & $<1$ & $1 \pm 0.00$ \\
\hline
\end{tabular}

${ }^{a}$ Each value is the mean of three replicates \pm standard deviation $(95 \%$ confidence levels). According to t-test, no statistical significant differences were observed within the same sampling between $0 \mathrm{~h}$ and $4 \mathrm{~h}(\mathrm{p}>0.05)$. 
the value of TVC. In the other three quarters of readings, no difference was observed. Provided that sufficient cooking had taken place, the display of the cooked burgers above $60^{\circ} \mathrm{C}$ for four hours did not increase the TVC content of this food.

To assess the microbiological content of cold meals, a lettuce salad and a potato salad were chosen. In these cases, the display period was again for 4 hours this time at a temperature below $5^{\circ} \mathrm{C}$.

For the lettuce salad (Table 3), the levels of TVC in- creased with statistical significance in $33.3 \%$ of samplings after the 4 hour long display. The maximum levels of TVC recorded were $7.60 \log _{10} \mathrm{cfu} / \mathrm{g}$ at time $0 \mathrm{~h}$ and $7.95 \log _{10} \mathrm{cfu} / \mathrm{g}$ at time $4 \mathrm{~h}$. Similarly, Enterobacteriaceae levels increased with statistical significance in $33.3 \%$ of samplings after the 4 hour long display. The maximum levels of Enterobacteriaceae recorded were $4.66 \log _{10} \mathrm{cfu} / \mathrm{g}$ at time $0 \mathrm{~h}$ and $4.84 \log _{10} \mathrm{cfu} / \mathrm{g}$ at time $4 \mathrm{~h}$.

For the potato salad (Table 4), TVC increased with

Table 3. Measurements ${ }^{\mathrm{a}}$ of TVC and Enterobacteriaceae in 12 samplings of lettuce salad at times 0 h (start of serving) and 4 $h$ (end of serving).

\begin{tabular}{|c|c|c|c|c|c|}
\hline \multirow{3}{*}{ Sampling } & \multirow{3}{*}{ Time } & \multicolumn{4}{|c|}{ Lettuce salad } \\
\hline & & \multicolumn{2}{|c|}{ TVC $\left(\log _{10} \mathrm{CFU} / \mathrm{g}\right)$} & \multicolumn{2}{|c|}{ Enterobacteriaceae $\left(\log _{10} \mathrm{CFU} / \mathrm{g}\right)$} \\
\hline & & Range & Mean value \pm S.D. & Range & Mean value \pm S.D. \\
\hline \multirow{2}{*}{$1^{\text {st }}$ sampling } & $0 \mathrm{~h}$ & $5.57-5.72$ & $5.67 \pm 0.09^{*}$ & $4.18-4.26$ & $4.2 \pm 0.05^{*}$ \\
\hline & $4 \mathrm{~h}$ & $6.23-6.28$ & $6.25 \pm 0.02^{*}$ & $2.10-2.60$ & $4.37 \pm 0.05^{*}$ \\
\hline \multirow{2}{*}{$2^{\text {nd }}$ sampling } & $0 \mathrm{~h}$ & $6.61-6.69$ & $6.65 \pm 0.04$ & $3.92-4.57$ & $4.3 \pm 0.34$ \\
\hline & $4 \mathrm{~h}$ & $6.46-6.66$ & $6.56 \pm 0.10$ & $4.26-4.63$ & $4.43 \pm 0.19$ \\
\hline \multirow{2}{*}{$3^{\text {rd }}$ sampling } & $0 \mathrm{~h}$ & $5.30-5.51$ & $5.41 \pm 0.10$ & $3.67-4.40$ & $3.93 \pm 0.41$ \\
\hline & $4 \mathrm{~h}$ & $5.23-5.62$ & $5.47 \pm 0.21$ & $3.72-4.15$ & $3.97 \pm 0.22$ \\
\hline \multirow{2}{*}{$4^{\text {th }}$ sampling } & $0 \mathrm{~h}$ & $6.95-7.60$ & $7.25 \pm 0.33$ & $4.56-4.66$ & $4.62 \pm 0.06^{*}$ \\
\hline & $4 \mathrm{~h}$ & $7.41-7.95$ & $7.67 \pm 0.27$ & $4.68-4.75$ & $4.72 \pm 0.03^{*}$ \\
\hline \multirow{2}{*}{$5^{\text {th }}$ sampling } & $0 \mathrm{~h}$ & $6.90-7.51$ & $7.16 \pm 0.31$ & $3.76-3.83$ & $3.8 \pm 0.04$ \\
\hline & $4 \mathrm{~h}$ & $7.32-7.46$ & $7.38 \pm 0.07$ & $3.74-3.93$ & $3.82 \pm 0.10$ \\
\hline \multirow{2}{*}{$6^{\text {th }}$ sampling } & $0 \mathrm{~h}$ & $5.26-5.45$ & $5.34 \pm 0.10^{*}$ & $2.88-2.93$ & $2.96 \pm 0.11$ \\
\hline & $4 \mathrm{~h}$ & $5.64-5.83$ & $5.71 \pm 0.10^{*}$ & $2.98-3.28$ & $3.14 \pm 0.15$ \\
\hline \multirow{2}{*}{$7^{\text {th }}$ sampling } & $0 \mathrm{~h}$ & $5.45-5.91$ & $5.62 \pm 0.25$ & $3.28-3.79$ & $3.6 \pm 0.28$ \\
\hline & $4 \mathrm{~h}$ & $5.56-5.87$ & $5.75 \pm 0.17$ & $2.73-4.23$ & $3.54 \pm 0.76$ \\
\hline \multirow{2}{*}{$8^{\text {th }}$ sampling } & $0 \mathrm{~h}$ & $5.65-6.59$ & $6.23 \pm 0.51$ & $4.26-4.66$ & $4.5 \pm 0.22$ \\
\hline & $4 \mathrm{~h}$ & $6.36-6.43$ & $6.39 \pm 0.04$ & $4.20-4.82$ & $4.51 \pm 0.31$ \\
\hline \multirow{2}{*}{$9^{\text {th }}$ sampling } & $0 \mathrm{~h}$ & $5.97-6.26$ & $6.11 \pm 0.14^{*}$ & $3.94-4.57$ & $4.27 \pm 0.32$ \\
\hline & $4 \mathrm{~h}$ & $6.32-6.81$ & $6.56 \pm 0.25^{*}$ & $4.15-4.84$ & $4.41 \pm 0.37$ \\
\hline \multirow{2}{*}{$10^{\text {th }}$ sampling } & $0 \mathrm{~h}$ & $5.26-5.65$ & $5.44 \pm 0.20$ & $3.36-3.65$ & $3.47 \pm 0.16^{*}$ \\
\hline & $4 \mathrm{~h}$ & $5.08-6.36$ & $5.83 \pm 0.67$ & $3.72-3.80$ & $3.77 \pm 0.04^{*}$ \\
\hline \multirow{2}{*}{$11^{\text {th }}$ sampling } & $0 \mathrm{~h}$ & $6.56-6.93$ & $6.78 \pm 0.20$ & $4.23-4.46$ & $4.35 \pm 0.12$ \\
\hline & $4 \mathrm{~h}$ & $6.79-7.11$ & $6.93 \pm 0.17$ & $4.34-4.73$ & $4.58 \pm 0.21$ \\
\hline \multirow{2}{*}{$12^{\text {th }}$ sampling } & $0 \mathrm{~h}$ & $6.11-6.23$ & $6.17 \pm 0.06^{*}$ & $2.76-2.98$ & $2.89 \pm 0.12^{*}$ \\
\hline & $4 \mathrm{~h}$ & $6.51-6.95$ & $6.68 \pm 0.24^{*}$ & $3.28-3.43$ & $3.34 \pm 0.08^{*}$ \\
\hline \multirow{2}{*}{ Total } & $0 \mathrm{~h}$ & $5.26-7.6$ & & $2.76-4.66$ & \\
\hline & $4 \mathrm{~h}$ & $5.08-7.95$ & & $2.10-4.84$ & \\
\hline
\end{tabular}

${ }^{a}$ Each value is the mean of three replicates \pm standard deviation ( $95 \%$ confidence levels); "Within the same sampling, indicates statistical significant differences between $0 \mathrm{~h}$ and $4 \mathrm{~h} ;(\mathrm{p}<0.05)$ according to t-test. 
Table 4. Measurements ${ }^{\mathrm{a}}$ of TVC and Enterobacteriaceae in 12 samplings of potato salad at times $0 \mathrm{~h}$ (start of serving) and $4 \mathrm{~h}$ (end of serving).

\begin{tabular}{|c|c|c|c|c|c|}
\hline \multirow{3}{*}{ Sampling } & \multirow{3}{*}{ Time } & \multicolumn{4}{|c|}{ Potatosalad } \\
\hline & & \multicolumn{2}{|c|}{ TVC $\left(\log _{10} \mathrm{CFU} / \mathrm{g}\right)$} & \multicolumn{2}{|c|}{ Enterobacteriaceae $\left(\log _{10} \mathrm{CFU} / \mathrm{g}\right)$} \\
\hline & & Range & Mean value \pm S.D. & Range & Mean value \pm S.D. \\
\hline \multirow{2}{*}{$1^{\text {st }}$ sampling } & $0 \mathrm{~h}$ & $4.79-4.93$ & $4.89 \pm 0.10$ & $1.78-2.68$ & $2.33 \pm 0.48$ \\
\hline & $4 \mathrm{~h}$ & $4.83-4.98$ & $4.9 \pm 0.07$ & $2.04-2.63$ & $2.39 \pm 0.31$ \\
\hline \multirow{2}{*}{$2^{\text {nd }}$ sampling } & $0 \mathrm{~h}$ & $3.81-4.11$ & $3.93 \pm 0.16$ & $1.48-1.85$ & $1.64 \pm 0.19$ \\
\hline & $4 \mathrm{~h}$ & $3.60-4.23$ & $3.87 \pm 0.33$ & $1.48-1.60$ & $1.56 \pm 0.07$ \\
\hline \multirow{2}{*}{$3^{\text {rd }}$ sampling } & $0 \mathrm{~h}$ & $4.65-4.74$ & $4.71 \pm 0.05$ & $2.08-2.28$ & $2.2 \pm 0.10$ \\
\hline & $4 \mathrm{~h}$ & $4.61-4.72$ & $4.68 \pm 0.06$ & $2.04-2.40$ & $2.23 \pm 0.18$ \\
\hline \multirow{2}{*}{$4^{\text {th }}$ sampling } & $0 \mathrm{~h}$ & $4.52-4.65$ & $4.59 \pm 0.07$ & $1.78-2.15$ & $1.97 \pm 0.19$ \\
\hline & $4 \mathrm{~h}$ & $4.64-4.72$ & $4.68 \pm 0.04$ & $1.85-2.11$ & $2 \pm 0.14$ \\
\hline \multirow{2}{*}{$5^{\text {th }}$ sampling } & $0 \mathrm{~h}$ & $4.56-4.68$ & $4.63 \pm 0.06$ & $1.70-2.20$ & $2.01 \pm 0.27$ \\
\hline & $4 \mathrm{~h}$ & $4.61-4.79$ & $4.72 \pm 0.10$ & $1.85-2.20$ & $2.05 \pm 0.19$ \\
\hline \multirow{2}{*}{$6^{\text {th }}$ sampling } & $0 \mathrm{~h}$ & $4.60-4.72$ & $4.68 \pm 0.06$ & $2.86-3.40$ & $3.13 \pm 0.27$ \\
\hline & $4 \mathrm{~h}$ & $4.69-4.78$ & $4.73 \pm 0.05$ & $2.99-3.40$ & $3.16 \pm 0.21$ \\
\hline \multirow{2}{*}{$7^{\text {th }}$ sampling } & $0 \mathrm{~h}$ & $5.93-5.98$ & $5.96 \pm 0.03$ & $2.15-2.28$ & $2.2 \pm 0.07$ \\
\hline & $4 \mathrm{~h}$ & $5.86-6.26$ & $6.02 \pm 0.21$ & $2.15-2.28$ & $2.22 \pm 0.07$ \\
\hline \multirow{2}{*}{$8^{\text {th }}$ sampling } & $0 \mathrm{~h}$ & $6.08-6.57$ & $6.31 \pm 0.25$ & $2.32-2.54$ & $2.43 \pm 0.11$ \\
\hline & $4 \mathrm{~h}$ & $6.08-6.46$ & $6.31 \pm 0.20$ & $2.41-2.75$ & $2.57 \pm 0.17$ \\
\hline \multirow{2}{*}{$9^{\text {th }}$ sampling } & $0 \mathrm{~h}$ & $5.80-5.86$ & $5.82 \pm 0.03^{*}$ & $1.95-2.54$ & $2.22 \pm 0.30$ \\
\hline & $4 \mathrm{~h}$ & $5.93-6.11$ & $6.01 \pm 0.10^{*}$ & $1.85-2.62$ & $2.28 \pm 0.40$ \\
\hline \multirow{2}{*}{$10^{\text {th }}$ sampling } & $0 \mathrm{~h}$ & $4.54-4.67$ & $4.62 \pm 0.07$ & $1.60-2.18$ & $1.95 \pm 0.31$ \\
\hline & $4 \mathrm{~h}$ & $4.59-4.80$ & $4.72 \pm 0.11$ & $1.90-2.15$ & $2.04 \pm 0.13$ \\
\hline \multirow{2}{*}{$11^{\text {th }}$ sampling } & $0 \mathrm{~h}$ & $3.61-4.11$ & $3.79 \pm 0.28$ & $1-1$ & $1 \pm 0.00^{*}$ \\
\hline & $4 \mathrm{~h}$ & $3.64-4.11$ & $3.81 \pm 0.26$ & $1-1.6$ & $1.4 \pm 0.35^{*}$ \\
\hline \multirow{2}{*}{$12^{\text {th }}$ sampling } & $0 \mathrm{~h}$ & $4.30-4.41$ & $4.37 \pm 0.06$ & $1-1$ & $1 \pm 0.00$ \\
\hline & $4 \mathrm{~h}$ & $4.15-4.63$ & $4.43 \pm 0.25$ & $1-1$ & $1 \pm 0.00$ \\
\hline \multirow{2}{*}{ Total } & $0 \mathrm{~h}$ & $3.61-6.57$ & & $1-3.40$ & \\
\hline & $4 \mathrm{~h}$ & $3.60-6.46$ & & $1-3.40$ & \\
\hline
\end{tabular}

${ }^{a}$ Each value is the mean of three replicates \pm standard deviation $(95 \%$ confidence levels $)$; ${ }^{*}$ Within the same sampling, indicates statistical significant differences between $0 \mathrm{~h}$ and $4 \mathrm{~h} ;(\mathrm{p}<0.05)$ according to t-test.

statistical significance in $8.3 \%$ of samplings after the 4 hour long display. The maximum levels of TVC recorded were $6.57 \log _{10} \mathrm{cfu} / \mathrm{g}$ at time $0 \mathrm{~h}$ and $6.46 \log _{10} \mathrm{cfu} / \mathrm{g}$ at time $4 \mathrm{~h}$. Similarly, Enterobacteriaceae levels increased with statistical significance in $8.3 \%$ of samplings after the 4 hour long display. The maximum levels of Enterobacteriaceae recorded were $3.40 \log _{10} \mathrm{cfu} / \mathrm{g}$ at time $0 \mathrm{~h}$ and $3.40 \log _{10} \mathrm{cfu} / \mathrm{g}$ at time $4 \mathrm{~h}$.

These results could be explained on the basis of an antagonism that takes place between native food microflora and human pathogens in fresh produce [21]. This native microflora, that constitutes of Pseudomonas spp., lactic acid bacteria and yeasts, competes with pathogens and it has been suggested that all these strains have an important role on maintaining the pathogens' numbers at safe levels [21-23]. In the case of fresh foods, a food with high levels of microflora (in the range of $5-6 \log _{10} \mathrm{cfu} / \mathrm{g}$ ) is less probable to allow the proliferation of pathogen microorganisms than a food (e.g. processed food) with lower levels of microflora (less than $3 \log _{10} \mathrm{cfu} / \mathrm{g}$ ) [24]. 


\section{Conclusion}

Our results suggest that the application of GHP and HACCP monitoring procedures should be improved in a number of hotel and catering units in Greece. Particular attention should be given to training programs and the evaluation of these. Given that tourism and catering industry in Greece usually employs personnel on a temporary basis and new personnel is employed at the start of each season, the insufficient training and subsequent application of disinfection and cleaning programs, reported here, should be rather alarming for the Greek food controlling authorities. However, during, serving either cold or hot meals for 4 hours, the numbers of TVC and Enterobacteriaceae have shown a statistically significant increase in $33.3 \%$ of cases in lettuce but this result could be considered as a strong suggestion that the legislative duration of $4 \mathrm{~h}$ display is sufficient to maintain satisfactory safety levels in both cold and hot meals.

\section{REFERENCES}

[1] Law 487/2000, FEK1219B, "Healthy Food in Compliance with Directive 93/43/EEC," Gazette of the Greek Republic, 2nd Edition, 2000, p. 1219. http://www.tsirkas.gr/files-nomos/ISO/1219b_00.pdf

[2] EC Regulation (No 852), "The Hygiene of Foodstuffs," 2004.

http://eur-lex.europa.eu/LexUriServ/LexUriServ.do?uri= OJ:L:2004:226:0003:0021:EN:PDF

[3] Canadian Food Inspection Agency, "Prerequisite Programs," Meat Hygiene Manual of Procedures, 2011. http://www.inspection.gc.ca/english/fssa/meavia/man/ch3 /table3e.shtml

[4] ISO 22000:2005, "Food Safety Management SystemsRequirements for Any Organization in the Food Chain," ISO 22000:2005, 2005.

http://www.iso.org/iso/catalogue detail?csnumber $=35466$

[5] EC Regulation (No 853), "Laying down Specific Hygiene Rules for the Hygiene of Foodstuffs," 2004. http://eur-lex.europa.eu/LexUriServ/LexUriServ.do?uri= OJ:L:2004:139:0055:0205:EN:PDF

[6] EC Regulation (No 854), "Specific Rules for the Organization of Official Controls on Products of Animal Origin Intended for Human Consumption," 2004.

http://eur-lex.europa.eu/LexUriServ/LexUriServ.do?uri= OJ:L:2004:139:0206:0320:EN:PDF

[7] Codex Committee on Food Hygiene, "Recommended International Code of General Principles of Food Hygiene," Food Hygiene Basic Texts, Food and Agriculture Organisation of the United Nations, World Health Organisation, Rome, 1997, pp. 1-32.

[8] Codex Committee on Food Hygiene, "HACCP System and Guidelines for Its Application," Food Hygiene Basic Texts, Food and Agriculture Organisation of the United Nations, World Health Organisation, Rome, 1997, pp.
$33-45$.

[9] FAO/WHO, "Statistical Information on Food-Borne Disease in Europe-Microbiological and Chemical Hazards," FAO/WHO Pan-European Conference on Food Safety and Quality (Agenda Item 4b, PEC 01/04), Budapest, 25-28 February 2002.

[10] P. Legnani, E. Leoni, M. Berveglieri, G. Mirolo and N. Alvaro, "Hygienic Control of Mass Catering Establishments, Microbiological Monitoring of Food and Equipment," Food Control, Vol. 15, No. 3, 2004, pp. 205-211. doi:10.1016/S0956-7135(03)00048-3

[11] Merck KgaA, "Chromocult Coliform Agar Presence/ Absence Membrane Filter Test Method for Detection and Identification of Coliform Bacteria and Escherichla coli in Finished Waters," Version 1.0, Merck Protocol 1.02136.0001 Envirocheck Contact C, 2000

[12] Microbiology of Food and Animal Feeding Stuffs, "Colony-Count Method," Horizontal Methods for the Detection and Enumeration of Enterobacteriaceae, Part 2, ISO 21528-2:2004, 2004.

http://www.iso.org/iso/search.htm?qt=ISO+21528-2\&sort $=$ rel\&type $=$ simple \&published $=$ on

[13] Microbiology of Food and Animal Feeding Stuffs, "Horizontal Methods for Sampling Techniques from Surfaces Using Contact Plates and Swabs," ISO 18593:2004, 2004.

http://www.iso.org/iso/search.htm?qt=ISO+18593\&sort=r el\&type $=$ simple \&published $=$ on

[14] G. L. Nortje, L. Nel, E. Jordan, K. Badenhorst, G. Goedhart, W. H. Holzapfel and R. J. Grimbeek, “A Quantitative Survey of a Meat Production Chain to Determine the Microbial Profile of the Final Product," Journal Food Protection, Vol. 53, No. 5, 1990, pp. 411-417.

[15] J. T. Paterson, "Microbiological Assessment of Surfaces," Journal Food Technology, Vol. 6, No.1, 1971, pp. 63-72.

[16] Food and Public Health Branch, "Microbiological Guidelines for Ready-to-Eat-Food," Food and Environmental Hygiene Department, Hong Kong, 2001.

[17] Department of Agriculture, "Trade and Consumer Protection, Fact Sheet for Food Processors-Coliform Bacteria," Division of Food Safety, State of Wisconsin, (dfs3047-1102), 2002.

[18] R. B. Tompkin, "The Use of HACCP in the Production of Meat and Poultry Products," Journal of Food Protection, Vol. 53, No. 9, 1990, pp. 795-803.

[19] C. Wallace and T. Williams, "Pre-Requisites: A Help or a Hindrance to HACCP?" Food Control, Vol. 12, No. 4, 2001, pp. 235-240. doi:10.1016/S0956-7135(00)00042-6

[20] R. E. Black, A. C. Dykes, K. E. Anderson, J. G. Wells, S. P. Sindeir, G. W. Gary, M. H. Hatch and E. J. Gangarosa, "Handwashing to Prevent Diarrhea in Day-Care Centres," American Journal of Epidemiology, Vol. 113, No. 4, 1981, pp. 445-451.

[21] C. H. Liao and W. T. Felt, "Analysis of Native Microflora and Selection of Strains Antagonistic to Human Pathogens on Fresh Produce," Journal of Food Protection, Vol. 64, No. 8, 2001, pp. 1110-1115. 

and Disinfection Procedures and Microbiological Monitoring of Hot and Cold Meals

[22] C. Nguyen-The and F. Carlin, "The Microbiology of Minimally Processed Fresh Fruit and Vegetables," Critical, Reviews in Food Science and Nutrition, Vol. 34, No. 4, 1994, pp. 371-401.

[23] M. L. Parish, L. R. Beuchat, T. V. Suslow, L. J. Harris, E. H. Garrett, J. N. Farbe and F. F. Busta, "Methods to Reduce/Eliminate Pathogens from Fresh and Fresh-Cut
Produce," Comprehensive Reviews of Food Science and Food Safety, Vol. 2, No. S1, 2003, pp. 161-173.

[24] J. M. Jay, "Do Background Microorganisms Play a Role in the Safety of Fresh Foods?" Trends in Food Science and Technology, Vol. 8, No. 12, 1997, pp. 421-424. doi:10.1016/S0924-2244(97)01093-5 